\title{
Analisis Persepsi Orang Dengan HIV (ODHIV) Terhadap Risiko Penularan COVID-19 Di Kota Padang Tahun 2021
}

\author{
M. Angga Mahalta, Rika Sabri, Mahathir \\ Program Studi Magister Keperawatan Fakultas Keperawatan Universitas Andalas, \\ Dekanat Fakultas Keperawatan Kampus Limau Manis Padang 25163 Padang, Sumatera Barat. \\ Correspondence email: antoikgunawan@gmail.com
}

\begin{abstract}
Abstrak. Orang yang hidup dengan HIV (ODHIV) merupakan kelompok yang memiliki sitem imun yang lemah. Selain HIV, dunia juga sedang dihadapkan pada pandemi COVID-19. Angka kejadian COVID-19 tiap waktunya terus mengalami peningkatan hingga gelombang ketiga saat ini. ODHIV menjadi kelompok yang perlu mendapatkan perhatian lebih dalam menghadapi pandemi ini. Salah satu cara untuk memulai tindakan pencegahan adalah dengan melihat persepsi dari agregat yang akan dilindungi. Tingkat kewaspadaan seseorang terhadap suatu kejadian bisa dilihat dari bagaimana pandangannya terhadap obyek yang akan dipersepsikan. Penggalian persepsi ODHIV dapat memberikan gambaran bagaimana mereka memandang dan menghadapi COVID-19. Desain penelitian menggunakan metode penelitian kualitatif dengan pendekatan fenomenologi. Pemilihan partisipan menggunakan teknik purposive sampling. Teknik analisa data menggunakan teknik Colaizzi. Didapatkan sepuluh tema dalam penelitian ini yaitu pandangan ODHIV tentang COVID-19, perasaan ODHIV dalam menghadapi COVID-19, kesadaran akan perbedaan kondisi imun dan sebagai kelompok rentan, keyakinan terhadap ARV memperkuat imun tubuh, pandangan ODHIV tentang risiko penularan COVID-19, pandangan ODHIV terhadap protokol kesehatan, aktivitas yang memperkuat sistem imun, dukungan sosial, adaptasi pelayanan puskesmas selama pandemi, persepsi ODHIV terhadap vaksinasi. Hasil penelitian menunjukkan bahwa ODHIV merupakan populasi rentan yang perlu mendapatkan perhatian lebih terutama di masa pandemi COVID-19 ini. Kerjasama antara petugas pelayanan kesehatan, pengambil kebijakan harus ditingkatkan untuk menjangkau dan melindungi populasi ODHIV.
\end{abstract}

Kata kunci: COVID-19; HIV; persepsi

Abstract. People living with HIV (PLHIV) are group that have a weak immune system. In addition to HIV, the world is also facing the COVID-19 pandemic. The number of COVID-19 cases every time continues to increase until the current third wave. People living with HIV are a group that needs more attention in dealing with this pandemic. One way to initiate preventive action is to look at the perception of the protected aggregate. A person's level of alertness to an event can be seen from how they see the object to be perceived. Exploring the perception of people living with HIV can provide an overview of how they view and deal with COVID-19. This research use qualitative research methods with a phenomenological approach. The selection of participants used purposive sampling technique. The data analysis technique used the Colaizzi technique. There were ten themes found in this study, the views of people living with HIV on COVID-19, feelings of people living with HIV in dealing with COVID-19, awareness of differences in immune conditions and being a vulnerable group, belief in ARVs strengthening the body's immune system, views of people living with HIV on the risk of transmitting COVID-19, PLHIV's views on health protocols, activities that strengthen the immune system, social support, adaptation of Puskesmas services during a pandemic, PLHIV's perception of vaccination. The results of the study show that people living with HIV are a vulnerable population that needs more attention, especially during this COVID-19 pandemic. Cooperation between health care workers and policy makers should be increased to reach and protect the population of PLWHIV.

Keywords: COVID-19; HIV; Perception

\section{PENDAHULUAN}

Orang yang hidup dengan HIV (ODHIV) merupakan kelompok yang memiliki sitem imun yang lemah. Pada ODHIV terjadi penurunan CD4 yang merupakan salah satu jenis sel darah putih yang berperan dalam sistem imun tubuh. Kelompok ini rentan terkena penyakit infeksi, stres, dan berbagai masalah kesehatan yang dapat mengganggu kualitas hidup. (WHO, 2019; Jordan, 2020). Oleh karena itu, penting adanya pengawasan dan pengetahuan yang tepat bagi ODHIV dalam proses perawatan, terlebih pada masa pandemi saat ini.

Pandemi COVID-19 mengakibatkan kekacauan di berbagai sektor. Selain menjadi permasalahan global, pandemi COVID-19 juga berdampak pada penurunan kualitas pelayanan HIV di beberapa fasilitas kesehatan mulai dari perhatian, sumber daya, dan personel yang dialihkan untuk memerangi COVID-19. Ini diperparah dengan diperkirakannya sekitar $19 \%$ pasien yang terinfeksi HIV tidak dapat memperoleh obat antiretroviral (ARV), serta beberapa lembaga pencegahan dan pengendalian HIV yang diubah menjadi pusat penanganan COVID-19 menolak pasien HIV untuk menggunakan persediaan ARV mereka (Adadi, 2020; Amimo, 2020; Cairns, 2020; Pinto, 2020; Sun et al, 2020). Hal ini tentunya akan mempengaruhi kondisi pelayanan dan kondisi pada pasien HIV sendiri. 
Peristiwa ini menjadi penting mengingat data yang terus bertumbuh dan berkembang setiap harinya. Menurut penelitian Kanwugu (2020) sejauh ini secara global 378 kasus infeksi COVID-19 pada ODHIV telah dilaporkan dengan mayoritas berasal dari Inggris dengan 101 kasus dan Amerika Serikat 122 kasus. Selain itu, Penelitian Vizcarra (2020) menemukan 51 ODHIV didiagnosis dengan COVID-19 Rumah Sakit Universitario Ramón y Cajal Madrid. Selanjutnya, Gervasoni (2020) mendapatkan 47 ODHIV yang terinfeksi virus ini. Sampai saat ini, angka-angka tersebut terus meningkat seiring dengan perbaikan pendokumentasiannya.

Proporsi rendah ODHIV di antara pasien dengan COVID-19 harus ditafsirkan dengan hati-hati karena ada beragam bukti tentang kontribusi HIV pada epidemi virus pernapasan sebelumnya. Fitzpatrick (2018) mengaitkan HIV dengan risiko yang lebih tinggi terpapar infeksi saluran pernapasan. Selain itu sebuah studi kohort berbasis populasi yang besar di Afrika Selatan oleh Boulle (2020) menemukan bahwa risiko kematian COVID-19 di antara ODHIV menjadi dua kali lipat dari mereka yang tidak HIV. Senada dengan Boulle, Bhaskaran (2021) menyimpulkan bahwa ODHIV di Inggris berisiko lebih tinggi terhadap kematian akibat COVID-19. Ini menunjukkan bahwa situasi terus berubah dengan berjalannya penelitian dan mengharuskan perawat komunitas meningkatkan perhatiannya kepada kelompok beresiko tinggi seperti ODHIV

Berdasarkan studi pendahuluan yang telah dilakukan peneliti, didapatkan data bahwa ODHIV mengatakan takut dan stres dalam menghadapi pandemi COVID-19 ini. Mereka mengatakan khawatir dengan kondisi komorbid yang dimilikinya akan menyebabkan mereka beresiko tinggi untuk terinfeksi COVID-19 dan mengalami perburukan yang cepat. Hal ini terjadi karena masih minimnya sumber informasi dan program yang khusus diperuntukkan bagi populasi beresiko seperti ODHIV.

Mengingat urgensi pandemi COVID-19 dan informasi yang berubah dengan cepat tentang penyakit tersebut, maka diperlukan kewaspadaan yang tinggi terhadap risiko penularannya diantara ODHIV salah satunya dengan mengetahui persepsi ODHIV terhadap risiko penularan COVID-19. Berdasarkan berbagai data yang telah disampikan sebelumnya, maka penulis tertarik untuk meniliti tentang "Analisis persepsi ODHIV terhadap risiko penularan COVID-19 di Kota Padang tahun 2021".

\section{METODE}

Penelitian ini menggunakan metode kualitatif dengan pendekatan fenomenologi. Populasi yang diteliti adalah Orang dengn HIV (ODHIV) yang berada di Kota Padang Sumatera Barat. Pemilihan partisipan dilakukan dengan menggunakan teknik snowball sampling. Teknik ini merupakan pengambilan sampel yang dilakukan secara berantai dari satu partisipan ke partisipan lainnya.

Peneliti memperhatikan prinsip etik dalam melakukan penelitian ini. Dimulai dengan menghargai prinsip autonomy pada ODHIV selama penelitian dengan cara memberikan penjelasan lengkap terkait penelitian, tujuan, hak partisipan, pilihan yang dapat bebas dipilih, dan menciptakan suasana yang nyaman dalam mengambil keputusan sehingga keputusan untuk terlibat dalam penelitian dapat tercipta. Prinsip beneficience diwujudkan dengan peneliti memberi jaminan tidak melakukan suatu tindakan yang berbahaya bagi ODHIV dan penggalian informasi ini merupakan suatu bentuk upaya untuk melindungi populasi berisiko seperti ODHIV dalam menghadapi risiko penularan COVID-19 dan diharapkan dapat menjadi sumber rujukan untuk optimasi pelayanan kesehatan bagi ODHIV.

Peneliti menerapkan prinsip confidentiality dengan memberikan jaminan kerahasiaan atau data informasi yang diperoleh partisipan hanya akan dipergunakan untuk kepentingan penelitian. Dan untuk prinsip justice partisipan mendapatkan perlakuan yang sama dan kesempatan yang sama dalam menjalani proses penelitian.

Pengumpulan data dalam penelitian dilakukan dengan wawancara mendalam (indepth interview) dan catatan lapangan (field notes). Pedoman wawancara disiapkan sebelum melakukan wawancara dan disusun berdasarkan teori yang relevan dengan masalah penelitian yang terkait. Pertanyaan yang digunakan bersifat terbuka dan tidak kaku, sehingga pertanyaan bisa berkembang selama proses wawancara berlangsung dengan tetap memperhatikan teori yang telah ditetapkan dalam penelitian.

\section{HASIL DAN PEMBAHASAN}

Pada penelitian ini didapatkan 10 tema yaitu:

Tema 1: Pandangan ODHIV tentang COVID-19

Tema ini diangkat dari tiga kategori yaitu penyakit yang berdampak pada pernafasan, penyakit yang berdampak pada daya tahan tubuh, dan penyakit yang cepat penularannya.

\section{Tema 2: Perasaan ODHIV dalam menghadapi COVID-19}

Tema ini diangkat dari dua sub tema yaitu perasaan takut di fase awal COVID-19 dan perasaan ODHIV setelah menjalani pandemi. Selanjutnya sub tema perasaan ODHIV setelah menjalani pandemi diangkat dari 3 kategori yaitu takut menghadapi COVID19, merasakan paranoid terhadap COVID-19, dan tidak takut menghadapi COVID-19.

Tema 3: Kesadaran akan perbedaan kondisi imun dan sebagai kelompok rentan 
Tema ini didapatkan dari dua kategori yaitu menyadari ODHIV dengan imun lemah dan sebagai kelompok rentan.

\section{Tema 4: Keyakinan terhadap ARV memperkuat imun tubuh}

Tema ini diangkat dari dua kategori yaitu ARV melindungi dari risiko infeksi, dan ARV menjaga daya tahan tubuh.

\section{Tema 5: Pandangan ODHIV tentang risiko penularan COVID-19}

Tema ini diangkat dari dua sub tema yaitu lebih rentan terpapar COVID-19 dan memiliki risiko yang sama dengan orang biasa.

\section{Tema 6: Pandangan ODHIV terhadap protokol kesehatan}

Tema ini diangkat dari tiga sub tema: cuci tangan, physical distancing, dan penggunaan masker. Sub tema cuci tangan terbentuk dari dua kategori yaitu: melakukan cuci tangan cara yang benar dan mencuci tangan dengan sabun atau hand sanitizer. Sub tema physical distancing diangkat dari dua kategori yaitu melakukan jaga jarak dan menghindari keramaian. Sub tema penggunaan masker terdiri dari empat kategori yaitu penggunaan masker lebih dari satu filter, penggunaan masker medis, penggunaan masker kain, dan yang penting masker.

\section{Tema 7: Aktivitas yang memperkuat sistem imun}

Tema ini diangkat dari 5 sub tema diantaranya konsumsi vitamin, olahraga, menjaga pola tidur/ istirahat, menjaga pola makan, dan berjemur.

\section{Tema 8: Dukungan sosial}

Tema ini terdiri dari 3 sub tema yaitu tidak ada dukungan lingkungan terdekat, ada dukungan berasal lingkungan terdekat, dan harapan ODHIV mendapatkan dukungan keluarga. Sub tema ada dukungan berasal lingkungan terdekat terdiri dari 2 kategori diantaranya mendapatkan dukungan dari orang tua, dan mendapatkan support dari sahabat. Selanjutnya sub tema harapan ODHIV mendapatkan dukungan keluarga juga terdiri dari 2 kategori yaitu keluarga lebih protect ke ODHIV dan pentingnya support keluarga.

\section{Tema 9: Adaptasi pelayanan puskesmas selama pandemi}

Tema ini terdiri dari 7 sub tema yaitu kecepatan pelayanan, rentang pengambilan obat, variasi obat/ obat tambahan, konsultasi, pendampingan, edukasi, dan program tambahan yang diharapkan dari layanan kesehatan.

\section{Tema 10: Persepsi ODHIV terhadap vaksinasi}

Tema ini diangkat dari beberapa sub tema yaitu pandangan ODHIV terhadap vaksin, alasan melakukan vaksinasi, kondisi tubuh setelah vaksin, dan tindakan setelah vaksin. Sub tema pandangan ODHIV terhadap vaksin didapatkan dari empat kategori yaitu vaksin penting untuk memperkuat dan mempertahankan imun tubuh, vaksin mengurangi dampak COVID-19, tidak diketahuinya perkembangan vaksin dalam tubuh, dan ketidakefektifan vaksin. Selanjutnya sub tema alasan melakukan vaksin terdiri dari 3 kategori yaitu kesadaran diri sendiri, masukan dari teman, dan tuntutan dari tempat mereka bekerja. Untuk sub tema kondisi tubuh setelah vaksin terdiri dari 2 kategori yaitu tidak ada efek (biasa saja), dan pusing, demam, flu, batuk, kerongkongan sakit setelah vaksin. Selain itu sub tema tindakan setelah vaksin juga terdiri dari 2 kategori diantaranya mengajak untuk vaksin, dan tidak menganjurkan untuk vaksin.

\section{Pembahasan \\ Pandangan ODHIV tentang COVID-19}

Saat ditanya mengenai COVID-19, ODHIV menyampaikan bahwa COVID-19 merupakan virus yang menyerang pernafasan manusia. Menurut WHO (2020) salah satu gejala COVID-19 ini adalah terjadinya masalah pernafasan seperti hidung tersumbat, batuk, sakit tenggorokan, kehilangan indera penciuman, hingga gejala berat seperti sesak napas hingga gagal napas. Ini diperkuat oleh penelitian Ruan (2020) yang gagal napas dengan tingkat kematian yang tinggi karena COVID-19.

Partisipan juga menyebutkan bahwa COVID-19 merupakan virus yang mengganggu daya tahan tubuh dan penyebarannya sangat cepat dan bisa menyerang siapa saja. Recalcati (2020) juga menyatakan hal serupa bahwa COVID-19 menyebar dengan mudah melalui kontak dari orang ke orang terutama yang memiliki daya tahan tubuh rendah. Daya tahan tubuh adalah kemampuan tubuh untuk menangkal semua jenis kuman yang akan masuk ke dalam tubuh (Wati, 2021).

Hal ini menjadi penting karena cara pandang seseorang ini nantinya akan berpengaruh terhadap praktik pencegahan COVID-19. Pandangan seseorang tentang suatu penyakit (COVID-19) menurut McEachan (2016) akan mengurangi kemungkinan infeksi dengan meningkatkan praktik pasien. Selanjutnya penelitian Wahyuningsih (2015) juga memaparkan bahwa perilaku seseorang dipengaruhi oleh keyakinan atau cara pandang individu terhadap suatu fenomena (COVID-19) untuk melakukan atau tidak melakukan tindakan tertentu. Sehingga dengan mengetahui pandangan ODHIV terhadap COVID-19 ini akan memudahkan perawat dalam menentukan rencana keperawatan yang akan diberikan untuk melindungi ODHIV.

\section{Perasaan ODHIV dalam menghadapi COVID-19}

Partisipan menyatakan ketakutan yang ia rasakan bersumber dari berita-berita di media yang menayangkan banyaknya korban jiwa yang berjatuhan setiap harinya. Mereka menganggap betapa virus ini luar biasa 
mematikan. Informasi tentang ancaman diketahui dapat meningkatkan tingkat ketakutan (Cauberghe, 2009; Muris \& Field, 2010; Mertens, 2018). Penelitian (Holman, 2014) membuktikan bahwa jika seseorang berulang kali terlibat dengan konten media terkait trauma selama beberapa jam setiap hari dapat memperpanjang pengalaman stres akut.

Selain itu, masih adanya kekhawatiran mengenai dirinya yang mengidap HIV dan sampai saat ini belum ditemukan obatnya juga menjadi suatu momok yang membuat partisipan takut untuk menghadapi virus baru ini. Hal ini sejalan dengan CDC (2020) yang menyatakan bahwa ODHIV mungkin khawatir tentang kerentanan mereka terhadap COVID-19, karena mereka yang memiliki kondisi kesehatan yang mendasarinya yang mengalami gangguan kekebalan memiliki risiko lebih tinggi untuk mengembangkan penyakit serius, terutama mereka yang memiliki penyakit penyerta dan/atau penyakit yang tidak dikelola dengan baik.

Partisipan menyampaikan jika saat ini sudah tidak takut lagi dalam menghadapi COVID-19 karena sudah mendapatkan informasi dari petugas kesehatan yang ada di pelayanan. Disisi lain, ada partisipan yang merasa biasa-biasa saja dan menganggap bahwa virus ini tidak jelas karena melihat justru orang-orang yang menjaga protokol kesehatan yang terkena COVID-19, malah orang yang kelihatan cuek tidak terkena COVID-19. Selanjutnya, partisipan lain mengungkapkan tidak ada ketakutan untuk COVID-19 karena ia telah menjalani epidemi HIV yang stigmanya luar biasa.

Selain ODHIV yang mengalami perubahan perasaan, peneliti juga masih menemukan ODHIV yang merasa takut atau khawatir dalam menghadapi COVID19. Partisipan menuturkan walaupun masih merasa takut, namun skala takutnya tidak sebesar ketika baru terjadi pandemi COVID-19. Menurut Pakpour dan Griffiths (2020) ketakutan dalam komunikasi kesehatan dapat mengubah sikap dan perilaku seseorang. Mereka mengasumsikan bahwa seorang individu akan berpartisipasi dalam peningkatan perilaku kesehatan ketika mereka merasa keparahan dan kerentanan dari suatu penyakit itu tinggi.

\section{Kesadaran akan perbedaan kondisi imun dan sebagai kelompok rentan}

Kesadaran ODHIV akan kondisi mereka sebagai kelompok rentan dan memiliki perbedaan kondisi imun dengan orang lain menjadi suatu yang krusial untuk melakukan perilaku pencegahan COVID-19. Dalam penelitian ini sebagian besar partisipan sepakat bahwa ODHIV merupakan salah satu kelompok rentan yang imun tubuhnya berbeda (lebih lemah) dari orang biasa. Mereka mengatakan bahwa kelompok ini tidak bisa diabaikan dalam menghadapi pandemi COVID-19 karena apabila diabaikan maka kondisinya bisa cepat drop dan butuh perhatian ekstra. Ini deperkuat oleh Center for Disease Control and Prevention (CDC) pada bulan Maret 2020 yang menyoroti orang yang hidup dengan HIV (ODHIV) sebagai populasi yang berisiko tinggi mengalami peningkatan keparahan dari COVID19 dibandingkan dengan populasi lainnya.

\section{Keyakinan terhadap ARV memperkuat imun tubuh}

Partisipan dalam penelitian ini memiliki keyakinan bahwa jika mereka disiplin dan teratur dalam konsumsi ARV akan meningkatkan imun tubuh mereka. Selain meningkatkan imun tubuh, penggunaan ARV yang rutin menurut partisipan akan menjaga kestabilan tubuh, meningkatkan daya tahan tubuh, dan juga membuat tubuh lebih sehat.

Walaupun tidak menutup kemungkinan bagi ODHIV untuk terinfeksi COVID-19, partisipan mengatakan akan ada perbedaan dampak antara mereka yang konsumsi ARV teratu dengan yang tidak/belum mengonsumsi ARV. Hingga saat ini literatur yang tersedia tidak memberikan bukti konklusif bahwa antiretroviral dapat melindungi individu dari infeksi COVID-19. Namun, kepastian bukti sangatlah rendah karena ukuran sampel yang kecil, dan ketidakpastian mengenai intensitas paparan (WHO, 2020).

\section{Pandangan ODHIV tentang risiko penularan COVID-19}

Saat wawancara dilakukan, salah satu partisipan berpendapat bahwa ODHIV tidak memiliki perbedaan risiko tertular COVID-19 jika dibandingkan dengan populasi umum apabila sudah mengonsumsi obat teratur dan menjalankan protokol kesehatan. Pernyataan ini sejalan dengan beberapa penelitian antara ODHIV yang dirawat di rumah sakit dengan COVID-19 menunjukkan hasil klinis yang sebanding dan risiko infeksi SARS $\mathrm{CoV} 2$ yang serupa bila dibandingkan dengan populasi umum, terutama pada mereka dengan infeksi HIV yang terkontrol dengan baik dengan konsumsi ARV dan dengan jumlah CD4 > $200 \mathrm{sel} / \mathrm{mm} 3$ dan menekan viral load (Guo et al, 2020; Gudipati et al, 2020).

Pernyataan bahwa ODHIV yang melakukan terapi teratur memiliki risiko yang sama dengan populasi umum dalam menghadapi HIV tidak menutup kenyataan bahwa mereka tetap merupakan populasi yang berisiko. Ini terlihat dari pernyataan partisipan yang mengemukakan pandangannya bahwa ODHIV merupakan populasi yang berisiko lebih besar untuk terinfeksi COVID-19. Hal ini lagi-lagi disebabkan kesadaran mereka akan kodisi tubuhnya yang sudah mengidap penyakit auto-imun seperti HIV.

Selanjutnya partisipan juga menyebutkan apabila mereka terpapar COVID-19 akan mengakibatkan efek yang lebih berat bahakan dua kali lipat lebih berat daripada orang biasa karena terdapat dua virus sekaligus yang menyerang daya tahan tubuhnya. Penelitian Zhu et al (2020) menyatakan ODHIV sebagai kelompok rentan terpapar COVID-19. Hal ini diperkuat oleh pernyataan Direktur Pencegahan dan Pengendalian Penyakit 
Menular Langsung, Kementerian Kesehatan RI (2020), yang menekankan bagi ODHIV yang mengkonsumsi obat ARV secara rutin, tetap harus waspada dengan potensi penularan COVID-19.

\section{Pandangan ODHIV terhadap protokol kesehatan}

Partisipan mengatakan mereka menerapkan cuci tangan menggunakan sabun atau hand sanitizer di kegiatannya sehari-hari. Mereka juga mengetahui bahwa cuci tangan itu tidak bisa asal-asalan dan ada tahaptahapnya agar tangan menjadi bersih sempurna. Namun pada saat di observasi akan kemampuan tersebut, partisipan tampak masih kebingungan dengan tata cara mencuci tangan yang baik dan benar.

Ada banyak bukti bahwa bertahun-tahun sebelum epidemi cuci tangan tetap menjadi area yang membutuhkan perbaikan (CDC, 2019). Tangan kita adalah faktor penting dalam transmisi mikroorganisme, pada kasus ini adalah virus COVID-19 (EdmondsWilson, 2015). Penularan silang organisme ini ke orang lain terjadi ketika kita gagal mencuci tangan secara efektif. Penelitian Erasmus et al (2010) memaparkan laporan dari berbagai negara menunjukkan bahwa tingkat kepatuhan kebersihan tangan diperkirakan hanya mencapai $40 \%$. Kesenjangan antara pengetahuan dan praktek ini tentunya perlu menjadi perhatian bagi tenaga kesehatan di pelayanan ataupun pemerintah untuk lebih menggencarkan lagi sosialisasi cuci tangan yang baik dan benar.

Tindakan selanjutnya yang dianjurkan adalah menjaga jarak (physical distancing). Tindakan ini penting dilakukan agar meminimalkan risiko ODHIV terpapar droplet orang sekitar kita yang berkemungkinan membawa virus COVID-19. Partisipan mengatakan sudah melakukan jaga jarak sekitar 1 sampai 2 meter baik itu di tempat kerja maupun di tempat lain. Studi yang dilakukan The Lancet (2020) memberikan bukti bahwa kebijakan jarak fisik minimal $1 \mathrm{~m}$ saat ini dikaitkan dengan pengurangan besar dalam infeksi, dan jarak 2 m mungkin lebih efektif. Selain menjaga jarak, partisipan mengaku juga telah menghindari kerumunan dengan mengurangi aktivitas diluar rumah, karena apabila terpapar COVID-19 tidak hanya akan membahayakan dirinya, namun juga keluarganya yang berada di rumah.

Semua partisipan menyatakan menggunakan masker untuk mencegah penularan COVID-19. Data yang dikemukakan The Lancet (2020) juga menunjukkan bahwa memakai masker akan melindungi seseorang dari infeksi virus COVID-19 ini. Banyak variasi jawaban yang didapatkan oleh peneliti saat bertanya mengenai masker. Ada partisipan yang menjawab kalau masker yang cocok itu adalah masker yang memiliki lebih dari satu filter. Partisipan selanjutnya menyatakan bahwa masker medis lebih efektif karena memiliki 3 filter dan sekali pakai. Selain itu ada juga yang berpendapat kalau masker kain pun bisa digunakan untuk pencegahan. Dari 7 orang partisipan dalam penelitian ini, satu partisipan menganggap masker apapun bisa kita gunakan untuk menghindari COVID-19 asal penggunaan dan perawatannya tepat. Pernyataan ini sejalan dengan anjuran WHO (2020) yang menyatakan penggunaan, penyimpanan dan pembersihan atau pembuangan masker yang tepat sangat penting untuk membuat kinerjanya seefektif mungkin.

\section{Aktivitas yang memperkuat sistem imun}

Protokol kesehatan saja tentunya tidak cukup efektif untuk melindungi ODHIV dari ancaman pandemi COVID-19. Beragam tindakan telah dilakukan ODHIV dalam rangka meningkatkan kekebalan imun tubuh dalam menghadapi pandemi ini. Aktivitas yang dilakukan partisipan antara lain mengonsumsi vitamin, olahraga, menjaga pola tidur dan istirahat, menjaga pola makan, serta berjemur. Yuliana (2020) memaparkan bahwa aktivitas fisik dan olahraga aman dan efektif dalam meningkatkan kebugaran kardiorespirasi, metabolisme, kualitas hidup dan juga meningkatkan imun ODHIV. Ini sejalan dengan yang disampaikan oleh partisipan, mereka melakukan aktivitas fisik dan olahraga untuk meningkatkan kondisi imun mereka.

Dalam banyak kondisi, mencapai dan mempertahankan nutrisi yang optimal dapat meningkatkan fungsi kekebalan individu, mengurangi kejadian komplikasi yang terkait dengan infeksi dan melemahkan perkembangan infeksi, pada kasus ini berkaitan dengan COVID-19 (Mahlungulu, 2007). Selain itu menurut Julia dalam Ika (2020), mengatakan bahwa tubuh manusia membutuhkan sinar matahari untuk membantu meningkatkan produksi vitamin D dalam tubuh.

\section{Dukungan Sosial}

Dukungan sosial menurut Apollo dan Cahyadi (2012) adalah sumber-sumber yang didapati individu dari orang lain yang dapat mempengaruhi kesejahteraan individu yang bersangkutan. Partisipan mengatakan bahwa keluarganya tidak terlalu ada andil dalam mendukung ODHIV menghadapi pandemi. Penelitian Naulha (2021) menunjukkan bahwa sebagian besar ODHIV tidak merasa mendapatkan dukungan sosial keluarganya. Hal ini bisa terjadi karena banyak dari mereka yang masih merahasiakan tentang kondisinya yang mengalami HIV, dan juga bisa diakibatkan karena tidak berada dalam satu tempat tinggal yang sama dengan anggota keluarga dan telah mandiri saat kontrol dan berobat.

Di sisi lain, bagi ODHIV yang lingkungan atau keluarganya sudah mengetahui kondisi ODHIV akan memberikan perhatian yang lebih semampu mereka walaupun tidak maksimal. Penelitian Mahathir (2015) menyebutkan bahwa ODHIV bisa mendapatkan dukungan dari lingkungan sosial terdekat lainnya yaitu 
dari teman yang memiliki permasalahan sama dan yang memiliki pengalaman yang sama sebelum nya.

Partisipan berharap untuk mendapatkan dukungan dari keluarga. Mereka berharap mendapatkan support dari keluarga agar mereka dapat terhindar dari infeksi COVID-19 dan memiliki semangat dalam menjalani pandemi ini. Support yang mereka harapkan pun tidak berlebihan malah menurut peneliti. Sambil menunduk dan dengan nada yang sedikit haru, harapan itu terlihat begitu sederhana seperti sekedar mengingatkan mereka untuk patuh protokol kesehatan, mengingatkan untuk minum obat ARV, sampai sekedar menyemangati ODHIV untuk menjalani kesehariannya.

Data yang didapat oleh peneliti ini sejalan dengan penelitian Mahathir (2015) yang mengatakan bahwa dukungan keluarga sangat dibutuhkan oleh seoarang ODHIV. Dukungan tersebut juga meningkatkan harapan hidup bagi ODHIV. Disini dibutuhkan kepekaaan tenaga kesehatan untuk memberikan pemahaman dan menganggap keluarga sebagai sebuah unit kesatuan yang harus dilibatkan dalam pelayanan.

\section{Adaptasi pelayanan puskesmas selama pandemi}

Tindakan pertama yang dilakukan oleh puskesmas tentu saja mengedukasi kelompok berisiko seperti ODHIV tentang risiko mereka terhadap penularan COVID-19. Pengetahuan yang baik tentang pencegahan COVID-19 juga menjadi dasar dalam sikap yang baik dalam perilaku pencegahan COVID-19, yang berarti pengetahuan berpikir memegang peranan penting dalam pembentukan sikap (Sari, 2017; Edison, 2020). Lalu Partisipan merasa bahwa pada saat pandemi ini pelayanan menjadi lebih cepat, dalam waktu 15 menit mereka sudah bisa mendapatkan ARV.

Memang pada fase awal pandemi mereka mengatakan mengalami kesulitan untuk mengakses ARV, namun kini sudah lebih lancar dimana mereka yang akses ARV nya patuh dan rutin akan diberikan obat langsung untuk 2 bulan (Tim Komunikasi Publik Gugus Tugas Nasional, 2020). WHO (2021) juga menyataakan tindakan memastikan bahwa orang memiliki akses ARV yang efektif dan perawatan kesehatan lain yang mereka butuhkan akan membantu meminimalkan risiko dari COVID-19.

Partisipan menyatakan bahwa puskesmas menambahkan pemberian paketan vitamin dan obat sesuai keluhan yang dirasakan saat akses ARV. Pernyataan tersebut senada dengan petugas puskesmas yang menyatakan bahwa pada saat pandemi ini pasien ditambahkan pemberian vitamin di paket pengambilan obatnya sesuai dengan stok yang tersedia. Selanjutnya partisipan juga menyatakan untuk konsultasi lebih mudah karena di puskesmas pengunjungnya tidak terlalu ramai. Petugas puskesmas menambahkan kalau di puskesmas juga sudah menerapkan pelayanan satu pintu untuk ODHIV bisa mengakses ARV ataupun ingin berkonsultasi.
Partisipan memiliki harapan agar pelayanan kesehatan bagi ODHIV semakin baik kedepannya. Partisipan melihat bahwa sosialisasi tentang risiko COVID-19 pada orang dengan HIV positif masih perlu ditingkatkan, melihat banyak teman-teman mereka yang masih belum mengerti tentang risiko tersebut. Selanjutnya, partisipan berharap agar diadakannya program pemeriksaan CD4 dan viral load rutin supaya mereka bisa mengetahui bagaimana kondisi imunnya dalam rentang waktu tertentu. Selain itu, ada juga partisipan yang mengharapkann penambahan obat dan terobosan terbaru dari pelayanan kesehatan ataupun dari pemerintah untuk melindungi ODHIV dari risiko penularan COVID-19.

\section{Persepsi ODHIV terhadap vaksinasi}

Sebagian besar memandang vaksin ini penting untuk memperkuat dan mempertahankan imun tubuh. Mereka melihat vaksin ini sangat berguna untuk membentengi diri mereka dari paparan COVID-19. Selanjutnya partisipan mengatakan dengan melakukan vaksin, ini akan dapat mengurangi dampak atau efek yang lebih parah apabila mereka terdiagnosa positif COVID-19. WHO (2020) saat ini merekomendasikan vaksin COVID-19 (AstraZeneca/Oxford, Johnson dan Johnson, Moderna, Pfizer/BionTech, Sinopharm dan Sinovac) aman untuk orang yang hidup dengan HIV.

Dari tujuh orang partisipan, satu orang partisipan mengatakan menolak untuk melakukan vaksinasi. Ini terjadi karena partisipan memandang vaksin itu sendiri adalah virus yang dijinakkan. Partisipan mengaku kalau ia tidak mau jika harus menanggung resiko (perburukan) kebelakangnya. Untuk mengatasi persepsi ini UNAIDS (2020) sebagai organisasi dunia yang bergerak untuk melindungi semua orang dengan HIV positif menyebutkan bahwa semua vaksin yang saat ini telah disetujui oleh Negara dipercaya aman untuk semua orang termasuk ODHIV. Sehingga tidak ada alasan bagi ODHIV untuk tidak melakukan vaksin saat ada kesempatan.

Ada banyak alasan yang disampaikan partisipan yang melatarbelakangi mereka untuk melakukan vaksinasi. Alasan pertama adalah kesadaran diri sendiri. Hal ini dapat timbul karena ODHIV menyadari kondisi imun mereka yang tidak stabil dan sewaktu-waktu bisa terpapar COVID-19. Selain kesadaran diri sendiri, partisipan mengaku berani melakukan vaksin setelah mendapat saran dan masukan dari teman atau lingkungan terdekatnya. Diperkirakan pada partisipan sudah terdapat keinginan untuk melakukan vaksin, namun masih ada ketakutan yang dirasakan karena mendengar isu-isu negatif mengenai vaksinasi. Dengan adanya dukungan dari lingkungan terdekat ini sangat membantu partisipan dalam mengambil tindakan untuk dilakukan vaksinasi. Berbeda dengan dua alasan sebelumnya, alasan ketiga yang peneliti dapatkan dari partisipan adalah karena tuntutan pekerjaan. Tempat dimana ODHIV bekerja 
sehari-hari menerapkan program wajib vaksin bagi seluruh karyawan sehingga partisipan terpaksa mau tidak mau melakukan vaksin pada dirinya agar tidak kehilangan pekerjaannya saat ini.

Setelah partisipan melakukan vaksin, peneliti ingin melihat apa saja yang mereka rasakan. Partisipan ada yang mengatakan bahwa tidak ada perbedaan yang dirasakan saat sebelum dan sesudah vaksin, ia tidak merasakan efek apapun seperti yang diceritakan orangorang setelah vaksin dan merasa aman-aman saja. Dilain sisi, partisipan selanjutnya mengatakan ada perasaan pusing dan kebas pada lokasi penyuntikan sesaat setelah dimasukkan vaksin. Selang satu hari kemudian, partisipan mengalami demam, flu, batuk dan sakit kerongkongan yang berlangsung lebih kurang selama 1 minggu. Ia mengatasi gejala yang ia rasakan dengan beristirahat.

Tindak lanjut dari partisipan setelah melakukan vaksin juga menarik perhatian peneliti untuk ditinjau, sehingga hal ini bisa menjadi pertimbangan untuk menjangkau ODHIV lain dalam program vaksin ini. Dua jawaban ditemukan peneliti yaitu menganjurkan orang lain untuk vaksin dan tidak menganjurkan. Beberapa partisipan mengatakan mau untuk mengajak keluarga, teman dekat, teman sesama penyintas HIV untuk melakukan vaksin, dikarenakan mereka menganggap vaksin akan bermanfaat nantinya bagi kesehatan mereka dan juga bagus untuk meningkatkan pertahanan tubuh terhadap serangan infeksi COVID-19. Tindakan ini sama dengan anjuran WHO (2020) yang menyebutkan bahwa orang yang hidup dengan HIV tidak boleh dikecualikan dari rencana akses vaksin COVID-19 terlepas dari status kekebalan mereka, dan negara harus memasukkan orang yang hidup dengan HIV sebagai kelompok prioritas untuk vaksinasi COVID-19 sesuai dengan konteks epidemiologi mereka. Jawaban kedua yang didapatkan dari partisipan adalah tidak menganjurkan. Dalam konteks ini mereka tidak melarang seseorang untuk vaksin, namun lebih ke arah mereka tidak tertarik dengan program vaksinasi yang sedang berlangsung.

\section{SIMPULAN}

ODHIV merupakan kelompok yang berisiko terpapar COVID-19. Pada kelompok ini mengetahui bahwa COVID-19 ini merupakan penyakit yang menyerang pernafasan dan daya tahan tubuh, serta merupakan penyakit yang cepat penyebarannya. Walaupun sudah ada ODHIV yang merasakan perubahan perasaan, ini tidak menutup fakta bahwa masih masih banyak juga yang merasa takut dan paranoid dalam menghadapi COVID-19 ini. Hal ini dikarenakan ODHIV khawatir jika nanti mereka terkena, akan berdampak pada keluarga. Selain itu mereka juga menyadari bahwa mereka merupakan populasi dengan imun lemah dan kelompok rentan.

ODHIV memiliki keyakinan bahwa konsumsi ARV rutin dapat memperkuat imun tubuh, menjaga kestabilan tubuh, dan menjadikan tubuh mereka menjadi lebih sehat. Walaupun demikian ODHIV mengungkapkan pandangan bahwa mereka memiliki risiko lebih besar bahkan hingga 2 kali lipat dibandingkan populasi umum. Namun dengan mengonsumsi ARV yang teratur dan menerapkan protokol kesehatan, ada ODHIV yang beranggapan bahwa risiko mereka sama dengan orang lain pada umumnya.

ODHIV sudah melakukan penerapan protokol kesehatan dalam kegiatan sehari-hari. Namun saat diobservasi masih banyak terdapat kesalahan terutama pada bagian cuci tangan. Selain itu untuk memaksimalkan pengaruh dari protokol kesehatan, ODHIV sudah menerapkan konsumsi vitamin, olahraga baik dengan olahraga rutin atau sekedar melakukan aktivitas fisik yang dapat mengeluarkan keringat, menjaga pola tidur dan istirahat, menjaga pola makan dengan meningkatkan konsumsi buah dan sayur ditambah konsumsi madu, dan berjemur.

Dukungan sosial dari keluarga dan lingkungan terdekat memiliki makna yang sangat mendalam bagi ODHIV dalam menghadapi kondisi pandemi COVID-19 saat ini. Selanjutnya ODHIV melihat bahwa adaptasi pelayanan puskesmas pada masa pandemi ini sudah cukup baik. Namun ODHIV masih melihat beberapa hal yang masih perlu ditingkatkan seperti sosialisasi tentang dampak COVID-19 ini terhadap orang dengan HIV positif seperti mereka, diadakannya program pemeriksaan CD4 dan viral load berkala, serta ODHIV berharap adanya penambahan jenis obat untuk melindungi mereka lebih baik lagi.

Alasan ODHIV melakukan vaksin antara lain kesadaran diri sendiri, masukan dari teman, dan tuntutan pekerjaan. Setelah divaksin, respon tubuh yang mereka rasakan sama dengan populasi umum lainnya. Ada yang tidak merasakan apa-apa, dan ada juga yang merasakan efek seperti pusing, demam, flu, batuk, dan kerongkongan sakit. Tindakan yang mereka ambil setelah vaksin terbagi menjadi dua, yang pertama mengajak keluarga dan lingkungan sekitar untuk vaksin, dan yang kedua tidak menganjurkan orang lain untuk vaksin. Dampak COVID-19 pada ODHIV lebih kurang sama dengan populasi umum, serta perawatan yang didapatkan pun sama. Masih belum dijumpai data pada penelitian ini tentang perbedaan dampak COVID-19 pada ODHIV.

\section{DAFTAR PUSTAKA}

Adadi P, Kanwugu ON. (2020) Living with HIV in the time of COVID-19: a glimpse of hope. J Med Virol. jmv.26118.

Adadi, P. (2020). HIV / SARS - CoV - 2 coinfection : A global perspective.

https://doi.org/10.1002/jmv.26321
(June). 
Amimo F, Lambert B, Magit A. (2020). What does the COVID-19 pandemic mean for HIV, tuberculosis, and malaria control? . Trop Med Health.48:32.

Apollo, \& Cahyadi, A. (2012). Konflik Peran Ganda Perempuan Menikah yang Bekerja Ditinjau dari Dukungan Sosial Keluarga dan Penyesuaian Diri.Jurnal Widya Warta, 02, 255-271.

Bhaskaran, K., Rentsch, C. T., MacKenna, B., Schultze, A., Mehrkar, A., Bates, C. J., Eggo, R. M., Morton, C. E., Bacon, S., Inglesby, P., Douglas, I. J., Walker, A. J., McDonald, H. I., Cockburn, J., Williamson, E. J., Evans, D., Forbes, H. J., Curtis, H. J., Hulme, W. J., Parry, J., ... Goldacre, B. (2021). HIV infection and COVID-19 death: a population-based cohort analysis of UK primary care data and linked national death registrations within the OpenSAFELY platform. The lancet. HIV, 8(1), e24-e32. https://doi.org/10.1016/S2352-3018(20)30305-2

Boulle, A., Davies, M. A., Hussey, H., Ismail, M., Morden, E., Vundle, Z., Zweigenthal, V., Mahomed, H., Paleker, M., Pienaar, D., Tembo, Y., Lawrence, C., Isaacs, W., Mathema, H., Allen, D., Allie, T., Bam, J. L., Buddiga, K., Dane, P., Heekes, A., ... Tamuhla, T. (2020). Risk factors for COVID-19 death in a population cohort study from the Western Cape Province, South Africa. Clinical infectious diseases : an official publication of the Infectious Diseases Society of America, ciaa1198. Advance online publication. https://doi.org/10.1093/cid/ciaa1198

Cairns G. (2020). Disruption to HIV treatment in Africa during COVID-19 pandemic could double HIV deaths, modelling studies warn. Accessed June 2, 2020. https://www.aidsmap.com/news/may2020/disruptionhiv-treatment-africa-during-covid19-pandemic-could-double-hivdeaths

Cauberghe, V., Pelsmacker, P. De., Janssens, W., Dens N. (2009). Fear, threat and efficacy in threat appeals: Message involvement as a key mediator to message acceptance. Accident Analysis and Prevention, 41 (2) (2009), pp. 276-285, 10.1016/j.aap.2008.11.006

CDC. 2020. Coronavirus Disease 2019 (COVID-19) in People with HIV. Centers for Disease Control and Prevention.

https://www.cdc.gov/coronavirus/2019-

ncov/specific-groups/hiv.html

CDC. HIV Continuum of Care (2017) [Internet]. 2019 [cited 2020 Mar 23]. Available from: https://www.cdc.gov/nchhstp/newsroom/2017/HI V-Continuum-of-Care.html

Center for Disease Control and Preventions. (2020). COVID-19 https://www.cdc.gov/coronavirus/2019-ncov diakses pada tanggal 22 September 2020
Edison dkk. 2020. Hubungan Peran Petugas dan Sikap dengan Perilaku Masyarakat Dalam Ayu, R, S., et al. / Perilaku Pencegahan Covid-19 / JPPKMI 1 (1) (2020) Pengelolaan Sampah Rumah Tangga. Ensiklopedia of journal, 2(2): 90-95.

Edmonds-Wilson, S. L., Nurinova, N. I., Zapka, C. A., Fierer, N., \& Wilson, M. (2015). Review of human hand microbiome research. Journal of dermatological science, $80(1), \quad 3-12$. https://doi.org/10.1016/j.jdermsci.2015.07.006

Erasmus, V. , Daha, T. J. , Brug, H. , Richardus, J. H. , Behrendt, M. D. , Vos, M. C. , \& van Beeck, E. F. (2010). Systematic review of studies on compliance with hand hygiene guidelines in hospital care'. Infection Control \& Hospital Epidemiology, 31, 283-294. 10.1086/650451

Fitzpatrick, M. E., Kunisaki, K. M., \& Morris, A. (2018). Pulmonary disease in HIV-infected adults in the era of antiretroviral therapy. AIDS (London, England), 32(3), 277-292. https://doi.org/10.1097/QAD.0000000000001712

Gudipati, R. K., Braun, K., Gypas, F., Hess, D., Schreier, J., Carl, S. H., Ketting, R. F., \& Großhans, H. (2021). Protease-mediated processing of Argonaute proteins controls small RNA association. Molecular cell, 81(11), 23882402.e8.

https://doi.org/10.1016/j.molcel.2021.03.029

Gervasoni C, Meraviglia P, Riva A, Giacomelli A, Oreni L, Minisci D, et al. (2020). Clinical features and outcomes of HIV patients with coronavirus disease 2019. Clin Infect Dis; ciaa579.

Guo Wei WH, Hua B, Jie L, Xiangnan W, Kai Z, Amakobe S. (2020). A rapid assessment of the impact of the new coronavirus pneumonia epidemic on the health needs of HIV-infected patients. Chinese J Epidemiol. 41:5.

Holman, E.A., Garfin, D.R., Silver R.C. (2014). Media's role in broadcasting acute stress following the Boston Marathon bombings. Proceedings of the National Academy of Sciences of the United States of America, 111 (1) (2014), pp. 93-98, 10.1073/pnas.1316265110

Ika. (2020). Berjemur Sinar Matahari Mampu Meningkatkan Kekebalan Tubuh. Universitas Gajah Mada, 1-2. Diambil dari https://www.ugm.ac.id/id/berita/19207-berjemursinar-matahari-mampu-meningkatkan-kekebalantubuh

Jordan, R. E., Adab, P., \& Cheng, K. K. (2020). Covid19: Risk factors for severe disease and death. The BMJ, 368, 1-2. https://doi.org/10.1136/bmj.m1 198

Kementrian Kesehatan. (2020). Situasi Perkembangan COVID-19. https://www.kemkes.go.id/ diakses pada tanggal 21 September 2020 
Mahathir, Wiarsih, W., Permatasari, H. (2015). Pengalaman Orang Dengan HIV/AIDS (ODHA) Dalam Memanfaatkan Pelayanan Kesehatan Di Kota DKI Jakarta. Universitas Indonesia

Mahlungulu, S., Grobler, L. A., Visser, M. E., \& Volmink, J. (2007). Nutritional interventions for reducing morbidity and mortality in people with HIV. The Cochrane database of systematic reviews, (3), CD004536. https://doi.org/10.1002/14651858.CD004536.pub 2

McEachan, R., Taylor, N., Harrison, R., Lawton, R., Gardner, P., \& Conner, M. (2016). Meta-Analysis of the Reasoned Action Approach (RAA) to Understanding Health Behaviors. Annals of behavioral medicine : a publication of the Society of Behavioral Medicine, 50(4), 592-612. https://doi.org/10.1007/s12160-016-9798-4

Mertens, G., Boddez, Y., Sevenster, D., Engelhard, I.M., Houwer J. De. (2018). A review on the effects of verbal instructions in human fear conditioning: Empirical findings, theoretical considerations, and future directions. Biological Psychology, 137 (2018) $\mathrm{pp}$. 49-64, 10.1016/j.biopsycho.2018.07.002

Muris, P., Field A.P. (2010). The role of verbal threat information in the development of childhood fear. "Beware the Jabberwock!". Clinical Child and Family Psychology Review, 13 (2) (2010), pp. 129-150, 10.1007/s10567-010-0064-1

Naulha, F., \& Sundari, R. (2021). Hubungan Harga Diri dan Dukungan Sosial Keluarga dengan Resiliensi pada Odha Saat Pandemi COVID-19. (April), 3845.

Pakpour, A. H., Griffiths, M. D., Chang, K. C., Chen, Y. P., Kuo, Y. J., \& Lin, C. Y. (2020). Assessing the fear of COVID-19 among different populations: A response to Ransing et al. (2020). Brain, behavior, and immunity, 89, 524-525. https://doi.org/10.1016/j.bbi.2020.06.006

Pinto RM, Park S. (2020). COVID-19 pandemic disrupts HIV continuum of care and prevention: implications for research and practice concerning community-based organizations and frontline providers. AIDS Behav.

Recalcati S. (2020). Cutaneous manifestations in COVID-19: a first perspective. Journal of the European Academy of Dermatology and Venereology : JEADV, 34(5), e212-e213. https://doi.org/10.1111/jdv.16387

Ruan, Q., Yang, K., Wang, W., Jiang, L., \& Song, J. (2020). Clinical predictors of mortality due to COVID-19 based on an analysis of data of 150 patients from Wuhan, China. Intensive care medicine, 46(5), 846-848. https://doi.org/10.1007/s00134-020-05991-x
Sari N dan Surahma AM. 2017. Pengetahuan, Sikap dan Pendidikan dengan Perilaku Pengelolaan Sampah di Kelurahan Bener Kecamatan Tegalrejo Yogyakarta. Jurnal medika respati,12(2): 74-84.

Sun S, Hou J, Chen Y, Lu Y, Brown L, Operario D. (2020). Challenges to HIV care and psychological health during the COVID-19 pandemic among people living with HIV in China. AIDS Behav

The Lancet HIV. (2020). Lockdown fears for key populations. The Lancet HIV, 7(6), e373. https://doi.org/10.1016/S2352-3018(20)30143-0

Vizcarra, P., Pérez-Elías, M. J., Quereda, C., Moreno, A., Vivancos, M. J., Dronda, F., ... Vivancos, M. J. (2020). Description of COVID-19 in HIVinfected individuals: a single-centre, prospective cohort. The Lancet HIV, 7(8), e554-e564. https://doi.org/10.1016/S2352-3018(20)30164-8

Wahyuningsih, N.P. (2015). Pengaruh Media Visual Nutrition Card Terhadap Perubahan Pengetahuan, Sikap dan Tindakan Anak Sekolah Dasar di SDN Keputih No.245 Surabaya. Universitas Airlangga, Surabaya.

Wati, S. W. (2021). 7 Hal Yang Ternyata Merusak Daya Tahan Tubuh Anda. https://hellosehat.com/sehat/informasikesehatan/merusak-daya-tahan-tubuh/

World Health Organizations. (2020). WHO Coronavirus Disease (COVID-19) Dashboard. https://covid19.who.int/ diakses pada tanggal 21 September 2020

World Health Organizations. (2021). WHO Coronavirus Disease (COVID-19) Dashboard. https://covid19.who.int/ diakses pada tanggal 18 Juli 2021

Yuliana. (2020). Olahraga yang Aman di Masa Pandemi COVID-19 untuk Meningkatkan Imunitas Tubuh. Jurnal Bali Membangun Bali, 1(2), 103-110. https://doi.org/10.51172/jbmb.v1i2.112

Zhu, F., Cao, Y., Xu, S., \& Zhou, M. (2020). Coinfection of SARS-CoV-2 and HIV in a patient in Wuhan city, China. Journal of Medical Virology, 2-3. https://doi.org/10.1002/jmv.25732 